Finally, it should be noted that this Colloquium should really be considered in conjunction with the two major exhibitions of the Festival, constantly referred to in the discussions, which regrettably could not for technical reasons be adequately illustrated by lantern slides. The great exhibition of the tribal sculpture at the fine new Musée Dynamique (planned by Professor Jean Gabus of Neuchâtel) displayed African art on an unprecedented scale both in historical depth and in geographical breadth, and perhaps provided the most concrete evidence of negritude yet seen. The exhibition of contemporary art at the Palais de Justice, on the other hand, was an almost uniformly embarrassing demonstration of the alienation of the contemporary artists as a result of excessive subservience to the International Style of Western Europe and America-pardonable enough so long as their patrons are almost exclusively non-Africans.

(Communicated by Mr. William Fagg, Chairman, United Kingdom Committee for the Festival)

\title{
The Third International Conference of Ethiopian Studies
}

The Third International Conference of Ethiopian Studies held at Addis Ababa, 3-8 April 1966, under the auspices of the Institute of Ethiopian Studies of the Haile Sellassie I University, was the first to take place in Ethiopia, the two previous gatherings having met in Rome and Manchester, in 1959 and 1963 respectively.

By far the largest of the series to date, it was attended by 116 participants. About half came from over a dozen countries, from the United States to the U.S.S.R. and from the Netherlands to Tanzania, the others being Ethiopians or other scholars resident in the country. No fewer than seventy papers were presented, ten by persons unable to attend. The largest number of papers, which geographically covered Ethiopia and the Horn of Africa, were in the fields of history and archaeology, linguistics, literature, and anthropology, other subjects including bibliography, economics, geography, law, political science, social medicine, music, and theology. The proceedings are to be published.

At the end of the proceedings it was decided to set up an International Committee for Ethiopian Studies composed of Professor Wolf Leslau of the University of California, Los Angeles; Professor Edward Ullendorff of the School of Oriental and African Studies, London; Professor J. Tubiana, of the École des Langues Orientales Vivantes, Paris; Professor E. Haberland of the University of Mainz; Professor L. Fusella of the University of Naples; Professor S. Strelcyn of the University of Warsaw; Dean Abraham Demoz of the Haile Sellassie I University's Faculty of Arts; and Professor Richard Pankhurst of the Haile Sellassie I University's Institute of Ethiopian Studies, who was also organizer of the Conference. The next Conference is to be held in Warsaw in 1969.

(Communicated by Professor Richard Pankhurst)

\section{Conference on Research in the Western Indian Ocean Region}

A CONFERENCE on research in Madagascar, the Comoros, Mauritius, Réunion, and the Seychelles, sponsored by the African Research Committee, was held at the Minnowbrook Conference Center of Syracuse University from 30 October to 2 November 1969. Participants representing the disciplines of social and cultural anthropology, musicology, sociology, social psychology, political science, and history included Philip Allen (Department of State); Frederick Burke (Syracuse University); Remi Clignet (Northwestern University); L. Gray Cowan (Columbia University); Norma McCloud (Tulane University); John Middleton (Northwestern University); Allen Rawick (Library of Congress); Aidan Southall, Chairman (Syracuse University); and Peter Wilson (Yale University). 
The conference concentrated on seeking a common understanding of the social background of the region and on exploring the extent to which linked inter-disciplinary and comparative studies would be fruitful. Four core studies of Madagascar would be carried out to establish the main range of variation in cultural and social structure throughout Madagascar, and would include urban and historical projects. Studies of the oceanic island region, particularly the Comoros, hitherto almost entirely neglected by research, would also be made. It recommended the establishment of an informal clearing-house which would institute and maintain contact between social scientists interested in the region and keep them up to date on relevant plans and work in progress. This would be most conveniently based at Syracuse University where the facilities of the Program of Eastern African Studies would be of considerable assistance. The conference also recommended that a detailed application should be drawn up to obtain funds for carrying out the studies, to attract and train graduate students, secure library facilities, and form appropriate ties with interested scholars and academic institutions overseas.

\section{Meeting of West African Archaeologists at Fourah Bay}

A GRoup of archaeologists, mostly from West African countries, met at Fourah Bay College under the auspices of the Institute of African Studies on 28 and 29 June. The participants were: Professor J. Desmond Clark (University of California, Berkeley); Professor Peter Shinnie (University of Ghana); Professor Thurstan Shaw (University of Ibadan); Mr. Ekpo Eyo (Deputy Director of Antiquities, Nigeria); Professor Donald Hartle (University of Nigeria at Nsukka); Professor Frank Willett (Northwestern University); Dr. J. H. Hugo (I.F.A.N., Dakar); Mr. S. G. H. Daniels (University of Ibadan); Mr. Guy de Beauchene (I.F.A.N., Republic of Niger); Mr. Graham Connah (University of Ibadan); Mr. David Calvocoressi (University of Ghana); Mr. R. N. York (Volta Basin Research Project, Ghana); and Mr. Paul Ozanne (University of Ghana). Each participant has been actively engaged on fieldwork in Africa and presented the results of his researches to the conference.

Among the recommendations made by participants were the creation of the post of archaeologist in the Institute of African Studies and the provision of a suitable building for the staff and collections of the Sierra Leone Museum. It was also decided to establish a journal of West African archaeology, with Professor Thurstan Shaw as editor, and to hold annual meetings of West African archaeologists when possible.

\section{'Africa in the Wider World'}

THe Institute of African Studies, Fourah Bay College, the University College of Sierra Leone, and the Committee for African Studies of the University of California, Berkeley, jointly held a seminar on the theme of 'Africa in the Wider World: the inter-relationship of area and comparative studies' at Fourah Bay College from 20 to 25 June. The following papers were presented:

I. Musicology

2. Art

3. Literature

4. Archaeology

5. History

6. Political Science

7. Economics
J. H. Kwabena Nketia, University of Ghana.

J. Newton Hill, the Ford Foundation.

African Literature in English: John Povey, University of California, Los Angeles.

J. Desmond Clark, University of California, Berkeley.

Arthur Porter, University of East Africa.

Carl G. Rosberg, University of California, Berkeley.

David Carney, Economic Commission for Africa. 